\title{
Rhabdomyolysis After Cocaine Consumption-Case Report
}

\author{
Thiago de Jesus Bacha ${ }^{1,3}$, Marco Aurélio Almeida de Oliveira ${ }^{1}$, Alcimar Marques de Araújo \\ Martins $^{1}$, Marilda de Souza Gonçalves ${ }^{4}$, Anamika Dhyani ${ }^{2}$, Emerson Silva Lima ${ }^{1}$, Rajendranath \\ Ramasawmy $^{1,5}$ and José Pereira de Moura Neto ${ }^{1,2 *}$
}

${ }^{1}$ Department of Ciências Farmacêuticas, Universidade Federal do Amazonas, Brasil

${ }^{2}$ Fundação Hospitalar de Hematologia e Hemoterapia do Amazonas, Brasil

${ }^{3}$ Centro de Instrução Guerra na Selva-CIGS, Manaus, Brasil

${ }^{4}$ Fundação Oswaldo Cruz-Centro de Pesquisas Gonçalo Moniz, Brasil

${ }^{5}$ Fundação de Medicina Tropical Doutor Heitor Vieira Dourado, Brasil

*Corresponding author: José Pereira de Moura Neto, Department of Ciências Farmacêuticas, Universidade Federal do Amazonas, Brasil.

To Cite This Article: Thiago de JB, Marco Aurélio Almeida de O, Alcimar Marques de AM, Marilda de SG, Anamika D, Emerson SL, Rajendranath R, José Pereira de MN. Rhabdomyolysis After Cocaine Consumption-Case Report. Am J Biomed Sci \& Res. 2019 - 5(2). AJBSR.MS.ID.000881. DOI: 10.34297/AJBSR.2019.05.000881

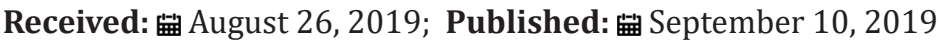

\begin{abstract}
Objective: Rhabdomyolysis, a potentially fatal syndrome, is characterized by degradation of muscular skeletal tissue trigger fatal complications such as acute renal failure.

Methods: Clinical evaluation and biochemical measurements were performed on a Brazilian soldier after he was admitted at the emergency department of the Military Hospital of Manaus in August 2014. A 23-year-old soldier reported having consumed about six grams of cocaine.

Results: Clinical laboratory measurement of serum showed a significant increase in the levels of indirect markers of muscle lysis. Serum creatine kinase fraction MM (CK) level increased up to $99.500 \mathrm{U} / \mathrm{L}$ and creatine kinase MB fraction (CK-MB) up to 6.500U/L. Changes in electrolytes also increased (sodium $=1.730 \mathrm{mmol} / \mathrm{L}$, potassium $=42.1 \mathrm{mmol} / \mathrm{L}$, phosphorus $=48.3 \mathrm{mg} / \mathrm{dl}$, chlorine $=1.243 \mathrm{mmol} / \mathrm{L}$ and magnesium $=36.1 \mathrm{mg} / \mathrm{dl}$ ). Changes in kidney functions also occurred (urea $=302.6 \mathrm{mg} / \mathrm{dl}$ and creatinine $=11.1 \mathrm{mg} / \mathrm{dL}$ ). The levels of albumin $(33.4 \mathrm{~g} / \mathrm{dl}$ ) and lactate dehydrogenase $\mathrm{LDH}$ $(22,545 \mathrm{U} / \mathrm{L})$ also increased. Further, qualitative tests for troponin and myoglobin were positive. Intervention: The soldier stayed in the intensive care unit (ICU) for five days.
\end{abstract}

Conclusions: Rhabdomyolysis syndrome was clinically identified due to consumption of cocaine. The soldier showed excellent clinical improvement after hyperhydration and treatment with discharged on the fifth day.

Keywords: Rhabdomyolysis; Cocaine; Military; Manaus

\section{Introduction}

Rhabdomyolysis is a potentially fatal syndrome characterized by degradation of muscular skeletal tissue, followed by the release of intracellular muscle components to the circulatory system. The release of electrolytes, purines and enzymes (such as creatine kinase, lactate dehydrogenase and aldolase) can cause potentially fatal complications such as acute renal failure [1]. The etiology of rhabdomyolysis is multifactorial. Muscle ischemia and cell destruction are the most observed in the patients. Illicit drugs, muscle stress, alcohol abuse, muscle diseases, trauma, defects of hereditary muscle enzymes, seizures and physical inactivity are characterized as major causes in adult populations [2,3]. Despite of the wide spectrum of etiology of rhabdomyolysis, the final pathogenetic pathway is common and is characterized by an increase in free electrolytes in the cytoplasm. Electrolyte changes lead to severe loss of the cell membrane homeostasis, especially by disrupting the pump $\mathrm{Na} / \mathrm{K}$ ATPase leading to hyponatremia, hypernatremia, hypokalemia, and hypophosphatemia, favoring the occurrence of rhabdomyolysis [4,5]. The diagnosis of rhabdomyolysis is based on symptoms such as muscle pain, weakness, presence or history of red or brown urine (myoglobinuria), elevated levels of creatine kinase fractions $\mathrm{MM}$ and $\mathrm{MB}$ that are not attributable to heart problems [6,7]. 


\section{Clinical Report}

A 23 years old male soldier was admitted to the emergency department of the Military Hospital-(HMAM), Manaus, Amazonas, in August 2014. The soldier reported symptoms of mental confusion, nausea, rapid heartbeat, sweating, fatigue, anuria and numbness in the lower limbs. He had consumed about 6 grams of cocaine in the last 12 hours. The following clinical laboratory tests were requested: creatine kinase-MM fraction, creatine kinaseMB fraction, lactate dehydrogenase, urea, creatinine, sodium, potassium, magnesium, phosphorus, chlorine, albumin, troponin, myoglobin and electrocardiogram. The soldier was administered with $500 \mathrm{~mL}$ of saline $(0.9 \%)$ while the laboratory tests were being carried out. After approximately 20 minutes of receiving medical care, the soldier fainted. He was immediately transferred to the Intensive Care Unit (ICU), where he remained for next 5 days.

Electrocardiogram was normal.,. After the soldier regained consciousness, the systolic and diastolic blood pressure were 160 and $120 \mathrm{~mm} \mathrm{Hg}$ respectively, with pulse rate of $103 / \mathrm{min}$. Pallor of the skin, mucous membranes and dry tongue were observed. detected Cardiac arrhythmia was detected. After evaluating the results of the laboratory tests [Figure 1 and Table 1], the soldier was prescribed the following medications:
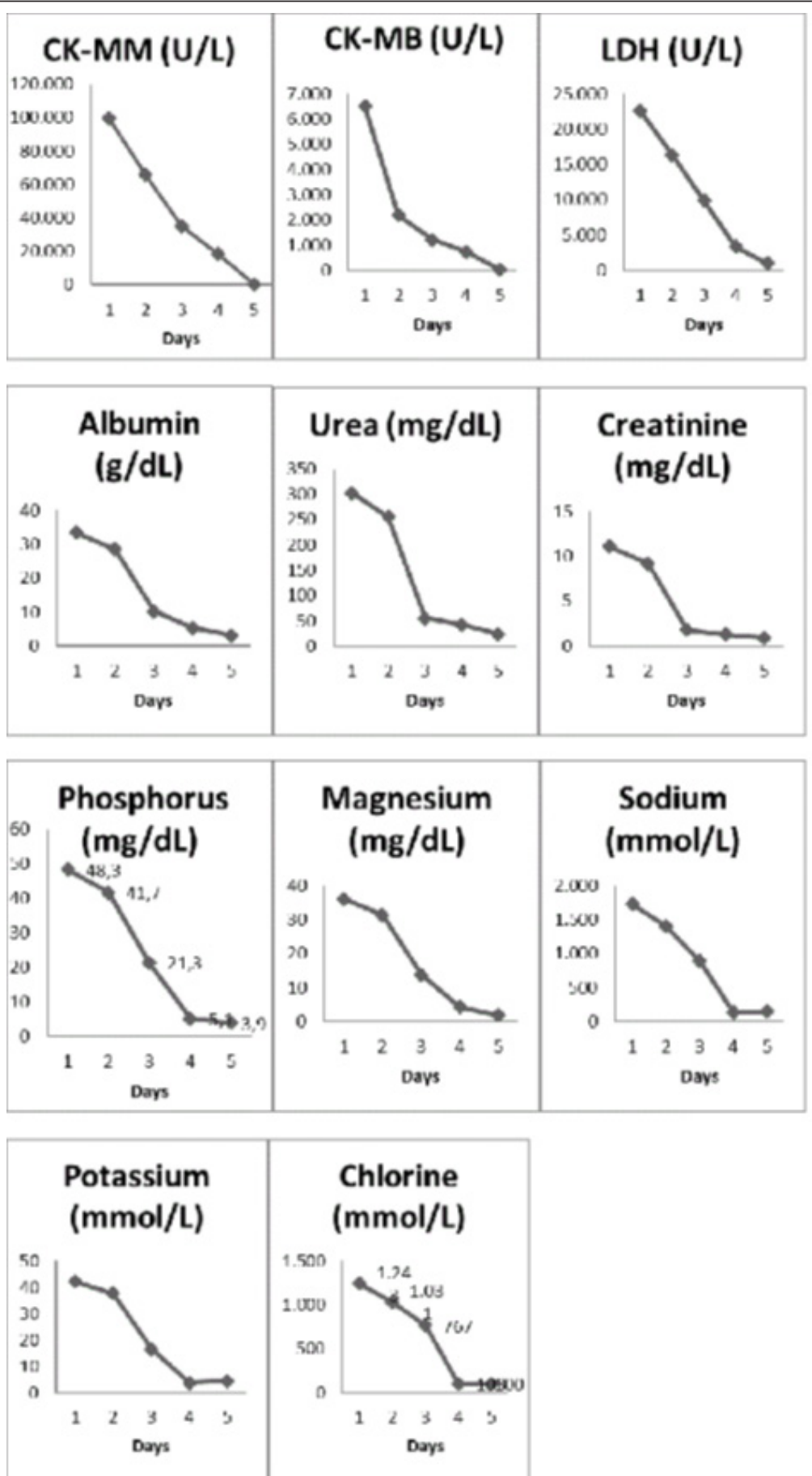

Figure 1: Results of biochemical tests performed on the soldier during the five days of hospitalization in HMAM 
Table 1: Qualitative troponin and myoglobin tests performed on the soldier during the five days of hospitalization.

\begin{tabular}{|c|c|c|c|c|c|c|}
\hline Tests & Day $\mathbf{1}^{\text {st }}$ & Day $\mathbf{2}^{\text {nd }}$ & Day $\mathbf{3}^{\text {rd }}$ & Day $\mathbf{4}^{\text {th }}$ & Day $\mathbf{5}^{\text {th }}$ & Reference Value \\
\hline Troponin & Positive & Positive & Positive & Negative & Negative & Negative \\
\hline Myoglobin & Positive & Positive & Positive & Negative & Negative & Negative \\
\hline
\end{tabular}

The treatment was initiated with saline $(0.9 \%)$ for hydration and reduce muscle spasms. Verapamil (5mg/2ml) hydrochloride and mannitol to increase diuresis, which consequently increased was administered to reduce blood pressure and improve the renal blood flow, and decreased the formation of occlusive oxygenation and relaxation of the heart muscle. Metoclopramide cylinders [Table 2].

Diazepam $0.5 \mathrm{mg}$ was administered to depress the central nervous system to relieve acute painful musculoskeletal conditions $(10 \mathrm{mg} / 2 \mathrm{ml})$ was used to reduce nausea and prevent vomiting. Dipyrone $(500 \mathrm{mg} / \mathrm{ml})$ was administered due to its analgesic, antipyretic and antispasmodic properties.

\begin{tabular}{|c|c|c|c|c|c|}
\hline \multirow[t]{2}{*}{ Medications } & Day $1^{\text {st }}$ & \multirow{2}{*}{$\begin{array}{c}\text { Day } \mathbf{2}^{\text {nd }} \\
\text { Diazepam } \\
5 \mathrm{mg} \text { (orally) }\end{array}$} & \multirow{2}{*}{$\begin{array}{c}\text { Day } 3^{\text {rd }} \\
-\end{array}$} & \multirow{2}{*}{$\begin{array}{c}\text { Day } 4^{\text {th }} \\
-\end{array}$} & \multirow{2}{*}{$\begin{array}{c}\text { Day } 5^{\text {th }} \\
-\end{array}$} \\
\hline & $\begin{array}{l}\text { Diazepam (orally) } 5 \mathrm{mg} \\
\end{array}$ & & & & \\
\hline & $\begin{array}{c}\text { Verapamil } \\
5 \mathrm{mg} / 2 \mathrm{ml} \text { (intravenous) }\end{array}$ & - & - & - & - \\
\hline & $\begin{array}{c}\text { Metoclopramide } \\
10 \mathrm{mg} / 2 \mathrm{ml} \text { (intravenous) }\end{array}$ & $\begin{array}{c}\text { Metoclopramide } \\
10 \mathrm{mg} / 2 \mathrm{ml} \\
\text { (intravenous) }\end{array}$ & - & - & - \\
\hline & $\begin{array}{l}\text { dipyrone } 500 \mathrm{mg} / \mathrm{ml} \\
\text { (intravenous) }\end{array}$ & $\begin{array}{l}\text { dipyrone } 500 \mathrm{mg} / \mathrm{ml} \\
\text { (intravenous) }\end{array}$ & $\begin{array}{l}\text { dipyrone } \quad 500 \mathrm{mg} / \\
\mathrm{ml} \text { (intravenous) }\end{array}$ & $\begin{array}{l}\text { dipyrone } \quad 500 \mathrm{mg} / \\
\text { ml (intravenous) }\end{array}$ & $\begin{array}{l}\text { dipyrone } 500 \mathrm{mg} / \mathrm{ml} \\
\text { (intravenous) }\end{array}$ \\
\hline & $\begin{array}{cc}\begin{array}{c}\text { Mannitol } \\
\text { (intravenous) }\end{array} & 10 \% \\
\end{array}$ & $\begin{array}{c}\text { Mannitol } \\
10 \% \text { (intravenous) }\end{array}$ & $\begin{array}{c}\text { Mannitol } \\
10 \% \text { (intravenous)) }\end{array}$ & - & - \\
\hline & Saline & Saline & Saline & Saline & Saline \\
\hline & $0,9 \%$ & $0,9 \%$ & $0,9 \%$ & $0,9 \%$ & $0,9 \%$ \\
\hline
\end{tabular}

\section{Discussion}

Cocaine nomenclature refers to cocaine salts, belonging to the alkaloid class, obtained from the leaves of the plant Erythroxylon coca [8]. The salts cocaine hydrochloride and sulfate are the two purest products in the refining process of coca. Cocaine salts are heat-resistant, non-volatile and have a melting point of $190^{\circ} \mathrm{C}$. They are popularly known as "dust", "talc", "snow", "flour", or "cachaça" $[9,10]$. Cocaine can be used according to its physical properties and purity. Features such as its low point of combustion and high solubility in water shows high absorption rate in mucosal areas by intranasal and intravenous routes and are referred as cocaine salts compared to crack that has high point of combustion and low solubility in water, thus generally used by inhalation [10]. Most of the administration routes absorb cocaine rapidly and it is these routes that determine the speed with which drug will begin its action, its concentration in blood as well as the duration of the euphoric effect. The psychoactive effects initiate faster when administered by intravenous route and inhalation, compared to the oral and intranasal administration. Cocaine salts are highly diffusible in water and are thermolabile, allowing its quick absorption by the nasal mucosa $[11,12]$.

The beginning of psychoactive effects produced by cocaine takes between eight seconds to 30 minutes and it remains effective for five to ninety minutes. The duration of the effect of intravenous and smoked cocaine is lower, which means that the consumer must administer multiple doses to achieve intense state of euphoria. The intravenous injection and inhalation of cocaine produce maximum levels of plasma concentration after three to five and one to three minutes from the time of administration, respectively [11,13]. The half-life of the metabolites lasts between four to six hours, and it is higher than the free cocaine, which is approximately 60 minutes. The concentration found in the blood corresponds faithfully to the amount exposed to the receptors. Blood, urine, and hair tests can be performed to verify the use of cocaine. Urine toxicology testing detects cocaine from 04 to 48 hours after consumption [14-16]. Cocaine use causes necrosis of skeletal muscle cells, releasing cellular constituents in the circulation, which may cause rhabdomyolysis. Laboratory and clinical manifestations show changes ranging from asymptomatic cases or elevations of muscle enzymes without significant clinical consequences, even complicated episodes of severe renal impairment or ventricular arrhythmias due to metabolic and electrolyte alterations $[17,18]$.

Carvalho et al. [17] described that muscle stretching or straining may lead to entrance of sodium into the cell, and secondarily to edema and thereafter death. On the other hand, it gives a calcium influx into the cell due to sodium-calcium exchange, which causes a persistent muscle contraction and consequent energy loss and cell death [17]. Excessive cell edema, especially during reperfusion of traumatized areas, induces large increases in muscle volume of lactate dehydrogenase (LDH) and creatine kinase (CK). The emergence of high levels of myoglobin and myoglobinuria, in conjunction with metabolic acidosis, which arises as a result of release of organic acids of necrotic cells and lactic acid during cell hypoxia, will determine the precipitation of uric acid crystals and myoglobin in renal tubules [19,20]. For the 
rhabdomyolysis diagnosis, indirect markers of muscle damage are dosed because of their low cost. The levels of creatine kinase (CK), lactate dehydrogenase (LDH), troponin and myoglobin are often used as muscle damage markers since these molecules are cytoplasmic enzymes and they do not have the ability to cross the barrier of sarcoplasmic membrane [21]. Among these enzymes, CK is often described as the best marker of indirect damage of the muscle tissue, especially for late diagnosis of rhabdomyolysis. Besides that, it is necessary to check the presence of hypercalcemia, hyperuricemia and hyperphosphatemia. The main therapeutic goal is to recognize and treat the complications as soon as possible, especially the electrolyte disturbances and acute renal failure $[22,23]$.

\section{Conclusion}

The patient on admission presented symptoms of rhabdomyolysis after consumption of large amounts of cocaine. Extremely high levels of CK, CK-MB and LDH were observed in the serum of the patient. The patient was discharged on the fifth day, compared to many cases who died as a result of rhabdomyolysis. Rhabdomyolysis is a multifactorial syndrome, and due to the absence of a specific marker for muscle lysis, sometimes this disease is confused with cardiac disease, making it difficult to diagnose. Many etiologies of acute kidney injury should always be related, an example, vasculitis, nephritis and rhabdomyolysis. We believe, significant data should be given to rhabdomyolysis, considering the cocaine use, especially with the intense physical activities. Due to the great clinical complexity and no known specific and genetic markers, indirect markers of muscle lysis are still in use for diagnosis of rhabdomyolysis.

\section{References}

1. Montero J, Lovesio C, Godoy MV, Ruiz G (2009) Rabdomiólise por spinning en nueve pacientes. Medicina Buenos Aires 69(1): 153-156.

2. Cervellin G, Comelli I, Lippi G (2010) Rhabdomyolysis: historical background, clinical, diagnostic and therapeutic features. Clincak Chemistry and Laboratory Medicine 48(6): 749-756.

3. Desjardins M, Strange B (2013) Pre-hospital treatment of traumatic rhabdomyolysis. Emergency Nurse 21(8): 28-33.

4. Giannoglou GD, Chatzizisis YS, Misirli G (2007) The syndrome of rhabdomyolysis: Pathophysiology and diagnosis. European Journal of Internal Medicine 18(2): 90-100.

5. Ronald C, Allison RC, Bedsole DL (2003) The Other Medical Causes of Rhabdomyolysis. The American Journal of The Medical Sciences 326(2): 79-88.

6. Mrkobrada S, Gnanakumar V (2014) The correlation of dystonia severity and serum transaminases in a child with a brain injury. Pediatric Neurology 51(4): 573-575.
7. Musumeci O, Brady S, Rodolico C, Ciranni A, Montagnese F, et al. (2014) Recurrent rhabdomyolysis due to muscle $\beta$-enolase deficiency: very rare or underestimated?. Journal of Neurology 261(12): 2424-2428.

8. Lyra L (2014) Concentração de proteínas totais, uréia, cálcio e fósforo em saliva total estimulada de dependentes químicos em desintoxicação. UFPR, Curitiba: PR.

9. Siqueira LP, Fabri ACOC, Fabri RL (2011) General, pharmacological and toxicological aspects of cocaine and its effects on pregnancy. Electronic Journal of Pharmacy 8(2): 75-87.

10. Martins Costa SH, Vettorazzi J, Cecin GKG, Maluf JMRA, Stumpf CC, et al. (2013) Crack: a nova epidemia obstétrica. Revista HCPA 33(1): 55-65.

11. Crespo Fernández JA, Rodríguez CA (2007) Bases neuroanatómicas, neurobiológicas y del aprendizaje de la conducta de adicción a la cocaína. Revista Latinoamicana de Psicologia 39(1): 83-107.

12. Conceição VN, Souza LM, Merlo BB, Filgueiras PR, Poppi RJ, et al. (2014) Study of Scott test using spectroscopic techniques: an alternative method for detecting cocaine hydrochloride and its addulterants in street drugs. New Chemistry 37(9): 1538-1544.

13. (2012) Cracké possível vencer. Retirado de, Brazil.

14. Pérez AO (2003) Was this individual poisoned by cocaine? (I): estimates based on the pharmacokinetics of the drug. Cuadernos de Medicina Forense (33): 5-12.

15. Corrêa CH, Oliveira LSG de, Assis JEA de, Barros RTC de (2014) Anestesia no paciente usuário de crack e cocaína. Revista Medica Minas Gerais $24(3)$.

16. Guollo F, Narciso Schiavon JL, Barotto AM, Zannin M, Schiavon LL (2015) Significance of alanine aminotransferase levels in patients admitted for cocaine intoxication. Journal of Clinical Gastroenterology 49(3): 250255.

17. Carvalho A, Raposo JN, João A, Namora J (2002) Rabdomiólise - breve revisão, a propósito de um caso. Medicina Interna 9(2): 80-82.

18. Clark BC, Manini TM (2016) Can KAATSU exercise cause Rhabdomyolysis? Clinical Journal of Sport Medicine 27(1): e1-e2.

19. Amaral (2015) Utilização terapêutica das estatinas: indicações, novas perspectiva e efeitos laterais a curto e longo prazo. Porto, Portugal p. $1-68$.

20. Filho JCCL, Ogawa MY, de Souza Andrade TH, Sami de Andrade Cordeiro Gadelha, Paula Frassinetti Castelo Branco Camurça Fernandes, et al. (2019) Spectrum of acute kidney injury associated with cocaine use: report of three cases. BMC Nephrol 20(1): 99.

21. Bulle DJ, Vitalis R, Paza L, Silva R da, Santos CE dos, Renner JD (2015) Control case study of creatine phosphokinase changes in users of a laboratory in the interior of Rio Grande do Sul. Revista Cinergis 16(2).

22. Scalco RS, Gardiner AR, Pitceathly RDS, Zanoteli E, Becker J, et al. (2015) Rhabdomyolysis: a genetic perspective. Orphanet J Rare Dis 10: 51.

23. Capaldo A, Gay F, Lepretti M, Gaetana Paolella, Stefania Martucciello, et al. (2018) Effects of environmental cocaine concentrations on the skeletal muscle of the European eel (Anguilla anguilla). Sci Total Environ 640641: 862-873. 